\title{
Faces de uma festa-espetáculo: redes e diversidades na montagem do ciclo junino em Caruaru*
}

\author{
EDSON FARIAS**
}

\begin{abstract}
R esumo: Ao tomar por dojeto o circuito de eventos articulados na festa-espetáculo em que se comemora o ciclo junino em Caruaru (PE), a proposta do artigo enfoca as redes alongadas de densas dependências sociofuncionais mútuas e os seus efeitos nãoprogramados sobre os universos simbólicos e os sistemas de práticas. Coserva-se para isto as reciprocidades entre instâncias formais e informais ajustadas nos esquemas de diversão, no tocante à conformação de zonas de entretenimento-turismo na cidade, por intermédio da triangulação composta pelas matrizes da cultura popular e pelos agenciamentos do mercado monetarizado na elaboração e uso de expressões lúdicas, ao lado da prestação de serviços de lazer, e os dispositivos do poder público. O acento da análise recai na estruturação do espaço de sociabilidade festiva, tanto nos vetores afinadbs com a lógica do entretenimento quanto nos elementos que configuram fónuns públicos transitórios de luta, negociação e reconhecimento público-afetivo.
\end{abstract}

Palavras-chave: festa-espetáculo; ciclo junino em Canuanu; diversidade e entretenimento.

Desde a última década, um fenômeno ganha relevo na agenda dos estudos socioculturais no B rasil, a saber, a conexão de matrizes culturais, a princípio reconhecidas como folclóricas e tradicionais, com o entretenimento, ensejando a peculiaridade institucional das festas populares regionais como grandes festivais de diversão e lazer. No interior desses espaços, os quadros de valores que definem as práticas lúdico-artísticas populares têm se mostrado hábeis à reatualização dos seus significados na integração com os mercados: gastronômico, de hospedagem e dos fluxos de transportes de passageiros, entre outros. Portanto, as festas-

\footnotetext{
* Trabalho apresentado à Sessão Temática VI - Cidade e Cultura: A Iteridade, Sociabilidade e Diversidade na Construção do Espaço, XI Encontro Nacional da Anpur.

** Professor do Programa de Pós-Graduação em Ciências Sociais da UFBA e pesquisador do grupo Cultura, M emória e Desenvolvimento.
}

espetáculo compreendem acontecimentos que compõem hoje um circuito de eventos-espetáculo cosmopolitas definidos em razão do forte apelo mercantil das atividades neles desenvolvidas, as quais estão voltadas para a prestação de serviços de diversão e turismo e situam-se nos fluxos translocalizados dos símbolos pelas redes midiáticas. N esse gênero de zonas de lazer, os fundos de conhecimentos coletivos e quadro de valores legítimos pautam as experiências no estabel ecimento de sistemas de práticas em que estão amalgamadas expressão e produção culturais; profissionalismo e brincadeira; ócio e negócio.

Desse modo, é preciso considerar as festasespetáculo em confluência e competição com outros elementos da cultura popular de massa. O bserva-se que estão incluídos nesses encadeamentos do entretenimento, além dos rodeios e do carnaval, o futebol, as corridas de carro, o 
milionário circuito do tênis internacional, a andústria cinematográfica hollyw oodiana, mesmo 0 mundo das artes (plásticas, cênicas, coreográficas e musicais), como se todos esses el ementos estivessem situados sobre esse eixo comum e transcendente às frontei ras das locali dades e das nações. I gualmente, a distância entre os níveis culturais e as discrepâncias distributivas dos recursos sociais são reacomodadas pela tendência à segmentação das audiências no seio de tal economia de símbolos. Por sua vez, as correlações socioculturais extensas que constituem as festas-espetáculo manifestam-se, principalmente, na programação semiótica das suas respectivas territorialidades. Vale observar que a montagem combinando show, nos pal cos, com a preocupação circense com as variedades ("atrações") e a organização padronizada dos serviços de comidas e bebidas está em sintonia com a ênfase em um diferencial capaz de manter a áurea folclórica da tradi ção regional, habilitada a distinguir cada evento no interior de roteiros de viagens turísticas, onde se incluem situações afins, as quais são potenciais concorrentes. Então, na contrapartida da importância da remuneração do capital investido na organização e no patrocínio dos eventos festivos, antes, destaca-se a espécie de ritual ização secular dos festejos. Nesse sentido, se, como chamam atenção alguns antropólogos, a ritualização implica específica condensação de significados formal izados em determinados comportamentos, com graus acentuados de redundância (Tambiah, 1985, p. 124-25), nas festas-espetáculo as práticas e símbolos reconhecidos pela rubrica do popular são concatenados ao primado da carnavalidade, que os sintetiza nos discursos, nas condutas e nas programações visuais dos espaços. Isto significa que os mesmos elementos devem estar capacitados a exteriorizar igual ideário a respeito da festa, na medida em que otimizem recursos, definindo uma ambiência programada para os excessos carnais e a euforia dos prazeres, da comicidade e da al egria, situada em um tempo liminar identificado à descontração.

A ritualização descrita ocorre no compasso da reorganização das várias faces constituintes dessas festas, a princípio incluídas no patrimônio lúdico-artístico da cul tura popular tradicional, a ponto de consagrá-las como manifestações massivas lúdicas, engendradas pela gramática da ampliação dos excedentes econômicos, assumindo o formato e a unidade de sentido de megaespetáculos públicos. Como observa a antropóloga M aria Celeste M ira, a alteração indica que 0 ethos carnavalesco da festa está na mesma direção da primazia conferida ao lazer pela sociedade urbana moderna, desde o fim da Segunda Guerra M undial. A Igo assim viabiliza mercadologicamente tais eventos no entrecruzamento de temporalidades, aliado ao atravessamento do caráter de exposição pública dos afetos e do apelo aos efeitos bombásticos de relaxamento das tensões, com a "lógica midiática do consumo e do espetáculo". Para a autora, o enlace deve ser compreendido à luz das transformações mais gerais na experiência das sociedades ocidentais. N esse sentido, argumenta, desde o fim da Segunda Guerra, os fatores responsáveis pela intensificação do consumo atuam na modulação das festas como espetáculos, pela importância fundamental assumida pelos "novos meios de comunicação de massa". Já que

no cinema, no rádio e nas revistas assiste-se à emergência de uma ética profundamente hedonista, voltada para o lazer, o entretenimento, a busca da felicidade aqui e agora, numa palavra, para o consumo. Os astros e estrelas se transformam em modelos dessa nova ética. Os corpos se desnudam, se erotizam para influenciar o consumo. A intimidade se transforma em espetáculo. (M ira, 1999, p. 111)

A o tomar por objeto o circuito de eventos articulados na festa-espetáculo em que se comemora o ciclo junino em Caruaru (PE), a proposta deste artigo enfoca, em termos teóricos, as redes alongadas de densas dependências sociofuncionais mútuas e os seus efeitos nãoprogramados sobre os universos simbólicos e os sistemas de práticas. Observando, para isto, o mapeamento empírico das reciprocidades entre instâncias formais e informais ajustadas nos esquemas de diversão, no tocante à conformação de zonas de entretenimento-turismo na cidade mediante a triangulação composta pelas matrizes da cultura popular, pelos agenciamentos do mercado monetarizado na elaboração e no 
uso de expressões lúdicas, ao lado da prestação de serviços de lazer, e pelos dispositivos do poder público. Logo, o acento da análise recai na estruturação do espaço de sociabilidade festiva, tanto nos vetores afinados com a lógica do entretenimento, isto é, de exposição e consumo de bens de diversão, quanto nos el ementos que configuram fóruns públicos transitórios de luta, negociação e reconhecimento público-afetivo. Desse modo, a problemática em foco diz respeito à el aboração dessas contemporâneas paisagens temáticas, nas quais ao consumo é atribuído papel-chave, seja na seleção e na propagação dos sentidos aspirados nas distintas interações, seja no desfecho dado à visibilidade de al gumas das práticas no concerto dos relacionamentos. No argumento, são considerados como usos e suas ressignificações estão na contrapartida da definição de estratégias de distinção pautadas na retomada e no deslocamento de uma diversidade de componentes mnemônicos (classe, geracionais, étnicos, regionais e gêneros), tecidos na textura étnico-histórica daquele nicho de práticas lúdico-artísticas referidas a uma tradição sertaneja.

Contudo, não se trata de somente apreender o espaço à maneira de suporte ou mero epifenômeno, seja de processos de maior monta, seja daquel es relati vos a encontros interpessoais. Compreendemos aqui o espaço como um vetor de coordenação das relações, elemento decisivo à recursividade das relações sociais, pela sua incidência direta na del imitação das escol has e, conseqüentemente, da atualização continuada de determinadas práticas. Intervenção cuja ocorrência se dá tanto no estabelecimento das disposições af etivas quanto na acomodação dos fundos geracionais de conhecimentos intersubjetivos. Logo, as conseqüências sobre as teias coletivas correspondem a uma forma que plasma as sucessões de episódios das mudanças socioculturais em objetividades mobilizadas e modeladoras da trama dos corpos. Por isso, a estratégia analítica parte da construção de um tipo ideal, o qual denomino de lugar de entretenimento-turismo, com a finalidade metodológica de percorrer, em seguida, os contornos próprios da experiência espacial em Caruaru.

\section{L ugares de entretenimento-turismo}

Se a opção na compreensão do espaço das ambiências-paisagem dos lugares de entretenimento-turismo é sociológica, deve-se a centralidade que nela ocupa a assertiva de Norbert Elias, a qual contesta "tempo" e "espaço" como grandezas distintas, mas as entende como complementares. Para ele, ambos são símbolos conceituais de tipos específicos de atividades sociais e institucionais, voltados a tipos também particulares de relações socioposicionais. No caso do tempo, a posicionalidade é verificada lançando mão de padrões de medida móveis, com a finalidade de detectar a sucessão dos episódios, o devir. Por sua vez, no espaço, as escalas de referências padronizadas abstraem os movimentos diante do objetivo de constatar as correlações posicionais de coisas, pessoas e objetos (Elias, 1998, p. 80-81). Portanto, simultaneamente obra e efeito, a paisagem atualizase nos sentidos que a formatam e conhecem, ou seja, na maneira como aqueles penetram e trasladam, incluem ou eliminam móveis. ${ }^{1} \mathrm{Na}$ permanência da sua aparência, a paisagem é então algo capaz de dotar de naturalidade os históricos encadeamentos coletivos de complementaridade e conflito. E a cidade como paisagem é a memória das intervenções, mas também o locus, 0 altar onde são cel ebradas as reciprocidades e a arena das lutas que consagra ou esmaga modos de atuar sobre a lembrança e de possibilitar 0 acesso ao conhecimento proveniente das memórias coletivas. A paisagem urbana guarda na textura os sinais dos jogos de poder - os confrontos e apropriações que tecem a tela apreendida como a cena legítima. $\mathrm{N}$ esse sentido, a paisagem urbana consiste em uma maneira de arrumar o espaço e traduz as trajetórias na construção de hegemonias sociais (Zukin, 1992). Não se trata de entender essa dimensão do espaço tão-somente pelos seus aspectos geológicos e arquitetônicos, mas reconhecer, na perenidade dos eventos col etivos

\footnotetext{
1. Ocupado em ol har a paisagem no Ocidente, o historiador Simon Schama identifica a última não com a matéria bruta da história geológica, mas a enxerga como sedimentações das relações humanas que moldam e são, igualmente, emolduradas por esse espaço-ambiente já prenhe de significados, na contrapartida das modalidades mentais de classificar e categorizar (Schama, 1996, p. 21-4).
} 
- as festas, por exemplo -, um elemento paisagístico também.

$\mathrm{Na}$ contrapartida do ol har sobre essas texturas espaciais e étnico-históricas, sobressaem as implicações categoriais, isto é, de que modo podemos aliar um vocabulário conceitual, adequado aos processos de maior abrangência, sem violentar as particularidades espaciais, ao contrário, tornando-os cúmplices. A tento justamente ao papel do lugar e do espaço no processo social contemporâneo, o geógrafo $M$ ilton Santos oferece uma alternativa, no momento em que apreende o espaço no interstício de sistemas de objeto e de sistemas de ações (Santos, 2002, p. 21). A seu ver, a coerência dessa construção teórica está na sua operacionalidade, por ser multimodal. De um lado, permitindo o recurso a categorias analíticas internas, como as de paisagem, configuração territorial, divisão territorial do trabal ho, espaço produzido ou produtivo, rugosidades e "formasconteúdo". Por outro, permite retomar as questões dos recortes espaciais, à maneira do tema da região e do lugar, das redes e das escalas. De modo concorrente, acrescenta 0 autor, a mesma perspectiva impõe-se à realidade no momento em que sugere os debates sobre a complementaridade entre uma "tecnosfera" e uma "psicoesfera". A ssim, no conteúdo geográfico do cotidiano, é possível apanhar o entrecruzamento das ordens mundiais e locais, entendendo a racionalidade do espaço "como um conceito histórico atual e fruto, ao mesmo tempo, da emergência das redes e do processo de globalização" (Santos, 2002, p. 22-23).

À luz desse norteamento teórico-metodológico, ancoramos nosso argumento na tese de que os espaços físicos, históricos e simbólicos das festas populares regionais do B rasil contemporâneo, por estarem enlaçados às forças simbólicas e socioeconômicas hegemônicas que os atravessam, mediante 0 implemento do mecanismo institucional do entretenimento e da economia de símbolos, contracenam com os novos aportes da acumulação do capital e das infra-estruturas de diversão, comunicação e informação na montagem dessas ambiênciaspaisagem aqui nomeadas de lugares de entretenimento-turismo. Pois, como sugere Pierre Bourdieu, a definição sociológica dos lugares imprescinde de conectar os condicio- nantes físicos do espaço, como localização e posicionamento (considerando extensão, volume e superfície ocupada por um indivíduo e/ou uma coisa), e o estatuto social da distinção naturalizado na espacial idade. N essa última, prevalece a lógica da posição em relação com (al to, baixo e entre, como hierarquias) e pela distância (de propriedades e recursos) relativa a outros lugares (B ourdieu, 1998, p. 160). Quer dizer, os lugares estão decididamente relacionados aos contextos estruturados das interações sociais, nos quais há a distribuição assimétrica de oportunidades e recursos entre os indivíduos que perseguem aí fins. Para 0 argumento geral dessa proposta, então, o encadeamento do mecanismo institucional do entretenimento é aqui reconhecido como exemplar da situação na qual estão articulados os sistemas abstratos com as práticas e símbolos, a princípio identificados com as memórias locais/regionais e nacionais. Isto sem perder de vista a ressignificação em tela, por remeter ao alcance (ou atravessamento) transterritorial da situação na qual o movimento ( 0 "fluxo" e o "desencaixe") define o estatuto e o regime sócio-simbólicos próprios da modernidade-mundo. ${ }^{2}$ Embora os perfis das transformações estejam de acordo com as especificidades assumidas nos diversos entrecruzamentos e contingenciamentos resultantes das desigualdades, com interferência no maior ou menor alcance das conexões socioculturais.

Há um aspecto, nesse sentido, ainda mais premente a ser destacado e corresponde ao entendimento da formação simbólica da cul tura popular, concatenada no percurso dessa trans-

2. Recorro às formulações de Renato Ortiz para compreender a modernidade como um modo de ser comungável como estilo de vida, no rastro de um processo civilizador mundial. Embora, vale frisar, isto não signifique para o autor a instauração de um absoluto ontológico ou uma totalidade sistêmica auto-referente. Ele sugere que a modernidademundo é parte de um articulado de forças hegemônicas no contexto globalizado centrípeto e desigual, e cuja flexibilidade advém da sua característica móvel de adequar-se às circunstâncias, em um movimento refratário às centralidades e à rigidez das fronteiras representativas das comunidades nacionais. A o reconhecer as categorias do entendimento de espaço e tempo na contraface das condições coletivas, 0 autor propõe as noções de "transversalidade" e "atravessamento", a fim de apreender o espaço na modernidade-mundo como intrínseco a um modo de vida específico, mas se tratando de uma espacialidade "transglóssica". Ou seja, constitui-se mediante 0 entrelaçamento de diferentes espacialidades decorrentes de histórias várias (0 rtiz, 1999, p. 6667). 
formação social ampla. A especificidade do nexo cultura popular elugar do entretenimentoturismo consiste, portanto, não somente na configuração do espaço materializada nos locais, isto é, o produto cul tural e turístico (a "atração") tomado em sua sincronia; igualmente diz respeito à processualidade em cujo interior ocorre a formação dos, para utilizar termos do universo do turismo, dados idiossincráticos dos lugares (nativos e cenários) em "recursos", e daí em produtos turísticos. Sendo estes ambientados em hierarquias cujas regras obedecem ao modo como o posicionamento dos seus el ementos está estruturado no encadeamento das relações sociais, nas fronteiras do dispositivo institucional do entretenimento.

Nesses termos, nosso problema adquire os seguintes contornos. Como sugere Thompson (1998), ${ }^{3}$ a modernidade corresponde igualmente a uma sensibilidade e a um concerto social cuja institucional idade internaliza as formas simbólicas nos esquemas de natureza tecnológica de veiculação das expressões humanas e nos circuitos de consumo ampliados. Consumo este regulado pelas agências empresariais amparadas na quantificação monetária e tendo o seu emblema estético e organizacional na ênfase depositada na evasão e na diversão, isto é, no entretenimento ou no espetáculo. No processo aqui em foco o que interessa é o entrelaçamento, em meio a lutas e complementaridades, de subsídios ideológicos, repertórios simbólicos, materiais e recursos de poder vários, de acordo com uma dinâmica civilizatória na qual os elementos engendrados pela modernidade encadeiam-se a

\footnotetext{
3. A rgumenta 0 autor que, à formação das sociedades modernas, para além dos processos de racionalização e secularização, contribuíram decididamente 0 surgimento e 0 desenvolvimento dos meios de comunicação de alcance ampliado. Pois, afirma, "[...] o uso dos meios de comunicação implica a criação de novas formas de ação e de interação no mundo social, novos tipos de relações sociais e novas maneiras de relacionamento do indivíduo com outros e consigo mesmo. Quando os indivíduos usam os meios de comunicação, eles entram em formas de interação que diferem dos tipos de interação face a face que caracterizam a maioria dos nossos encontros quotidianos. Eles são capazes de agir em favor de outros fisicamente ausentes, ou responder a outros situados em locais distantes. De um modo fundamental, o uso dos meios de comunicação transforma a organização espacial e temporal da vida social, criando novas formas de ação e interação, novas maneiras de exercer 0 poder, que não está mais ligado ao compartilhamento comum" (Thompson, 1998, p. 13-14).
}

outras tradições, entre as últimas, aquelas classificadas como "costumes do povo". No tocante à grande tradição ${ }^{4}$ moderna, ao se tornar hegemônica, estaria marcadamente destacada pela tendência cosmopolita à ruptura, ou seja, pelas transformações permanentes e pela individuação, tendo por contrapartida o impulso à integração crescente em uma coordenação sistêmica da diferenciação simbólica e institucional. 0 dado intrigante, já anotado, está no fato de as festasespetáculo aqui enfocadas fazerem contracenar, justamente, peculiaridades da grande tradição da modernidade com o tipo específico de reatualização de significados, os quais de início estariam inscritos nos parâmetros de convicções referendadas em uma normatividade paroquial comunitária. Isto, ao se insinuarem como lugares de entrecruzamento do entretenimento e da cultura popular vislumbrada como "folclórica". 5

4. Por grande tradição, fazemos referência ao centro ou aos centros societais designados simbolicamente pela autonomia em resolver situações de tensão vicejadas nas interações sociais, estabelecendo com base nele(s) periferias sujeitas à reestruturação, conforme os cânones consagrados das "visões, concepções e regras autônomas" (Eisenstadt, 1991, p. 51). Algo assim redunda na demarcação de fronteiras societárias, no interior das quais a estruturação e a interligação de agentes e fatores sustentam limites endógenos, entre outros, os da diferenciação na divisão do trabalho ou do trato com a racionalização das práticas ou 0 do controle das ações políticas.

5. Vale anotar que a concepção de uma cultura popular tradicional está inscrita nas condições sócio-históricas em que o objetivo de forjar unidades de sentido, tendo por recursos as heterogeneidades étnico-históricas situadas no território dos Estados nacionais, propiciou a elites artísticointelectuais a oportunidade de exercícios de classificação e nomeação fundamentais no estabelecimento dos patrimônios culturais habilitados a evocar a nação como um valor central, em se tratando do Brasil pela teoria das mesclas étnico-culturais (Farias, 2004). Por outro lado, a classificação folclórica do popular, ou a classificação mesma como cultura popular, implica assim o eixo sobre o qual se ergue a legitimidade de um segmento de práticas destacadas do mundo social cotidiano na modernidade. Pois tal categorização corresponde à racionalização discursiva de ímpeto tradicionalizante e antiquário, levada a cabo por intelectuais (acadêmicos, jornalistas, romancistas e outros). Racionalização esta básica à sistematização e ainda para conferir sentido próprio às práticas e símbolos, dispondo-os antagonicamente ao "moderno", aos identificá-los à tradição. 0 que os distingue e delimita é o traço diacrítico que unificaria uma multiplicidade de fenômenos, tendo por característica comum não apenas o rústico e o primitivo arcaizante, mas estando embasada seja no teor étnico (e racial) da "origem comum" que lhes é particular, seja na indicação de igual origem sociológica no seio coletivo do "homem do povo" (de perfil classista ou não) ou no engate de um e outro (ver Ginzburg, 1987, p. 16-17). 
Espaços no interior dos quais ocorre a definição das posições e negociações entre val ores "tradicionais" e "modernos"; "locais", "regionais", "nacionais" e "globais" pelos agentes aí agrilhoados, na interface com o agenciamento do mercado cultural mais amplo.

Sob tal ponto de vista, as teias de interdependências da estrutura social urbano-industrial e de serviços estão implicadas com os remanejamentos ou a geração de diversidades sóciosimbólicas na cidade, na medida em que há mútuo engendramento tanto com os arcabouços de verdades culturais reciprocamente compartilhadas quanto com a ecologia urbana, além dos meios de vida nela acionados. A final, é por intermédio das interfaces de planos institucionais com as situações de experiência dos agentes sedimentadas no delineamento das temporalidades e espacialidades que esse movimento de "desencaixe" se dispõe na regulação da produção e dos usos cotidianos. Trata-se do atravessamento dos sistemas de práticas, ou seja, dos mecanismos de normatização (regidos pelos costumes ou por contratos de natureza racional legal) dos meios de apropriação e de externar os afetos pelos critérios da condição cosmopolita, na qual segmentos sociais se fazem predominantes pelo volume, pela natureza e qualidade de recursos envolvidos na sua conduta de consumo, tendo, por isso, ascendência na imputação de sentidos sobre as demais facções. Configuração social em que os equilíbrios de poder estão diretamente vinculados aos domínios do consumo, no qual se entrecruzam a economia capitalista e o complexo informático-comunicacional, entremeado pela sociedade de consumidores, cuja racionalidade articula a ampliação dos fatores de lucratividade do capital ao peso adquirido por uma economia simbólica. Caracterizada pelo comércio de signos, nesta 0 Iúdico e a lógica da aparência e da exibição são valorados na contrapartida da geração de disposições (e também estratégias), devotadas à elaboração e à ressignificação de estimas e imagens individuais e col etivas (B auman, 2001, p. 159-161). Logo, para a compreensão das festas-espetáculo como lugares de entretenimento-turismo, devemos chamar a atenção para como nelas se sedimentam e adquirem forma os entrelaçamentos das disposi ções dos agentes e os específicos fundos geracionais de conhecimentos internos aos modos de compressão de espaço e tempo com essa rede de longa extensão da sociedade de consumidores.

A ssim, no plano macroestrutural, é preciso sublinhar o fato de os processos de modernização em que o crescimento das atividades de serviços de lazer e entretenimento, entre as quais a turística, no B rasil, e sua expansão por sobre diversas faces da sociedade nacional, ocorrem no bojo do que alguns autores chamaram de desenvolvimento de um "capitalismo tardio" dependente. Tal desenvolvimento estaria, complementam alguns dos intérpretes, em consonância com os imperativos monopolistas dos Estados nacionais centrais de uma economia capitalista cada vez mais de perfil financeiro e obediente à regulação fordista periférica do capital transnacionalizado, incrementada desde a década de 1960 (ver Fiori, 1999, p. 33-34). Por sua vez, a definição do perfil de um padrão estrutural das interdependências funcionais urbano-industriais e de serviços ganha contornos cada vez maiores no último intervalo de quatro décadas, no qual a população urbana passou a representar $78,36 \%$ dos atuais 170 milhões de habitantes da sociedade-nação (IBGE, 2002). A inda que a distribuição irregular da riqueza estivesse traduzida nas discrepâncias no plano das classes sociais e das regiões do país, são nessas mesmas circunstâncias em que ocorre 0 crescimento sem precedentes históricos da produção e do consumo de bens materiais e intangíveis, compartilhando da disseminação da população assalariada. 0 mercado de bens simbólicos ampliados tem suas margens igualmente estendidas, em um instante em que os bens simbólicos tornam-se alvo de investimento econômico e a temática da brasilidade é deslocada para uma cultura popular moderna materializada no complexo urbano-industrial e de serviços (Ortiz, 2001, p. 204). Exatamente, a materialidade turística é alçada a um patamar elevado e com ingerência no mundo da vida cotidiana, diretamente em conluio com a lógica desenvolvimentista que se torna o ideário hegemônico no país. 0 número de hotéis, por exemplo, aumenta de 663 unidades, em 1966, para 3.327 vinte anos depois (Trigo, 2000, p. 161-162). 
A s interligações entre essas teias técnicomercantis, vinculadas ao ritmo da economia capital ista, desenham um abrangente e complexo território, cujos efeitos alcançam diferentes escalas e posicionalidades. A brangência em sincronia com as condições peculiares das suas respectivas unidades culturais e considerando, ainda, as discrepâncias distributivas embutidas no cotidiano dos lugares que as abriga, além ainda dos enlaçamentos entre a graduação dos níveis de prestígio e os ef eitos dos estigmas. No tocante à situação atual do circuito de festas regionais no Brasil, tem-se o singular movimento de coordenação e diferenciação funcional em níveis mais acentuados de integração sel etiva das pessoas e símbolos referidos aos sistemas de práticas lúdico-artísticas populares. A dministradores e patrocinadores, ainda o gradiente nuançado de produtores e consumidores, estão conectados pelo espetáculo das imagens (sonoras, visuais e gustativas), no interior de um encadeamento funcional extenso e hierárquico do entretenimento e sob pressão, em suas escolhas, da rede heterogênea e assimétrica de consumidores culturais. Situação de contato e comunicação, na qual se modificam tanto 0 espaço do "nós" quanto a noção mesma de alteridade (A uge, 1997, p. 85-87). As reelaborações no armazenamento simbólico das experiências, mediante as reorientações das memórias e das linguagens, têm impacto na autoimagem de indivíduos e grupos, por incluírem novos dispositivos de percepção e conhecimento. Com isto, compreendem modificações subjetivas e intersubjetivas na coordenação das ações, já que, desde agora, interagem parâmetros de compreensão, validade, enfim, expectativas mútuas intrínsecas ao modo como o incremento quantitativo dos elementos, no interior do formato da festa-espetáculo, dispõem as condutas não apenas de manei ra complementar e desigual. Estão, também, entrelaçadas tensa e concorrencialmente no que tange à visibilidade eao reconhecimento público nesse tecido social qual itativamente distinto pela sua densa extensão e ávida circulação, sintetizado em "zonas de translocalidade" (A ppadurai, 1996, p. 44), em virtude da funcionalidade decorrente da natureza de lugares do entretenimento-turismo.
Por constituir o propósito deste trabal ho apreender as correlações das posições entre coisas, pessoas e objetos na conformação das ambiências-paisagem dos lugares de entretenimento-turismo, nossa premissa é que prevalecem, nessas espacialidades, os códigos referidos à dimensão cultural do consumo, os quais permeiam diversidades étnico-históricas e geográficas. Códigos cuja faculdade de ativar diálogos e promover consensos intra e intergrupais ocorre no acesso e uso dos bens materiais e intangíveis, especificando comunidades de sentido. Porém, de modo inverso, contribuem fortemente para o incremento de fraturas, já que os sinais emitidos nessas práticas estabelecem fronteiras, comunicam distinções e hierarquias, no mesmo compasso em que sublinham diferenças (Canclini, 1995, p. 86).

\section{Paisagem-ambiência no ciclo junino de Caruaru}

No entanto, é marcada por uma espécie de polêmica, a um só tempo moral e ontológica, a natureza dos lugares de entretenimento-turismo. 0 foco da celeuma é o dado artificial e espetacular intrínseco à codificação dessas paisagensambiência, na medida em que a tematização habilitada a diferenciar o espaço envolveria a montagem seletiva do lugar-cenário, mediante as intervenções do poder público associado às forças imobiliário-financeiras e do mercado da diversão, visando enobrecer determinada área para fins de remuneração do capital. A concretude adquirida pelo projeto dar-se-ia pelo recurso a técnicas de paisagismo e à extração de tudo quanto não fosse pertinente à programação turística, com o objetivo de enfatizar a combinação entre excitação e relaxamento (Sorkin, 1992, p. 205-232).

A ssim, diante da extensão tomada pela atividade turística e tendo por contrapartida 0 aumento no volume das viagens desses visitantes ávidos de novidades, desde o final da Segunda Guerra, durante a "Era de Ouro" do Ocidente capital ista, no livro The image, D aniel B oorstin reconhece na prática turística uma falsa experiência. Para ele, estaria ela calcada no consumo de simulacros, de uma realidade-artefato 
confeccionada para atender às expectativas geradas pelas programações e publicidades especializadas. Desse modo, B oorstin identifica uma postura "inautêntica", e o turismo co-participaria da estetização mistificante da realidade, ou melhor, do fabrico de "pseudo-eventos", nos quais prevalecem o clichê e os termos de um conhecimento medíocre (B oorstin, 1973, p. 99). Já em 1973, o sociólogo também norte-americano Dean $\mathrm{M}$ acCannell propõe-se a corrigir interpretações como as de B oorstin. R etomando o esquema de Goffman, $\mathrm{M}$ acC annell sugere 0 estudo da experiência turística com base na polaridade ideal-típica entre "frente" ("from") e "fundo" ("back"), mas sem tomá-los de maneira estanques e sim considerando-os termos de um mesmo contínuo. A seu ver, isto permitiria cotejar tanto a dimensão "real", quanto a produzida como "espetáculo", aquela a ser exibida, nos lugares turísticos. Teríamos o plano da autenticidade quando 0 visitante penetra e deixa-se invadir pelas regiões de "fundo", aventura-se no desconhecido e não-programado (M acCannell, 1973, p. 589-603). O utra vez, na década de 1990, M arc A ugé propõe identificar os lugares turísticos como "não-lugares" e resgata a perspectiva do inautêntico. Sendo marcos da aceleração dos fluxos, emblemática da "supermodernidade", para ele, tais espaços seriam desprovidos de profundidade histórica e afetiva, "já que nada está em seu próprio terreno, porém tampouco no terreno de outros" (A uge, 1993, p. 28), ao resultar dos deslocamentos realizados pelas viagens de turistas. Tãosomente ter-se-ia

[...] o espaço dos outros sem a presença dos outros, o espaço constituído em espetáculo, espetáculo em si mesmo atrelado nas palavras e nos estereóti pos que o comentam de antemão, valendo-se da linguagem convencional do folclore, do pitoresco ou da erudição. (A ugé, 1993, p. 29)

A figura conceitual do "pós-turista", desenhada por U rry e Lash (1994), a princípio implicaria uma ruptura com as concepções anteriores. Tratar-se-ia da seguinte situação: enquanto os turistas convencionais, das "massas", seriam alvo de ilusões, o "pós-turista" da pós-modernidade tiraria partido das simulações, penetraria aí como em um jogo de disfarces. $\mathrm{N}$ ão obstante, entendo que a última proposição revela, por um caminho inversamente si métrico, o mesmo dilema presente nos demais autores. Em todos as elaborações, a dificuldade reside em como lidar com a relação, na experiência turística, entre o que é reconhecido como efêmero e artificial e o identificado à sinceridade. $N$ ão será esse 0 ângulo pelo qual trarei 0 problema nesta pesquisa. Creio que a experiência turística tem por característica precisamente a atitude não da busca de uma autenticidade, mas a partici pação no jogo das imagens. Isto diferencia o turista moderno dos viajantes; algo simmeliano, para os últimos a aventura significa a radical idade de infringir os limites da vida e da morte (ver Simmel, 1988). A o turista moderno, a programação é a condição mesma do deslocamento e esta penetra não apenas as rotas, mas igualmente o teor dos destinos. Penso que a caracterização desses espaços deve considerar que o lugar de entretenimento e turismo igualmente depende da cumplicidade estabelecida entre as condições étnico-históricas e geopolíticas e os públicos ansiosos pelas imagens de unicidade, no instante de experimentação dos móveis cênicos da paisagem. Diante dos quais ganha concretude o ideário da escolha, na decisão tomada pelo viajante em relação àquela opção que se apresenta a ele mais cativante.

Quero propor que o lugar do entretenimento e turismo define-se seja em razão de consistir em uma descontinuidade temporal, espacial e simbólica implicada na lógica interna à dimensão espácio-temporal do ócio (N icolas, 1996, p. 3956), na qual se inscreve socialmente a institui ção do entretenimento; seja pelo fato de a sua extraordinariedade corresponder a um permanente jogo com os efeitos do fascínio, no qual a descontração e 0 autocontrole perfazem a unidade de interdependências configuradora do espaço da experiência da diversão, que atrela mutuamente visitantes e os fatores dos locais e decide o sentido das suas ações e da paisagem. Isto na medida em que tal cumplicidade deflagra uma mobilidade ao não-familiar, ou seja, no movimento em que 0 agente turista desloca-se a esse lugar, sabendo que deverá voltar àquele ponto de partida no término do tempo planejado 
do ócio. Porém, o deslocamento pretendido deve preservar-Ihe o bem-estar, na contrapartida da promessa de libertação individual da morosidade cotidiana e mediante a mobilização de artefatos de excitação ou de relaxamentos prazerosos no intercâmbio dinamizado. 0 que, por sua vez, subentende determinado consórcio entre 0 extraordinário e o ordinário, o formal e o espontâneo, a brincadeira e a seriedade, o risco e a segurança, o sonho e o real. A característica da liminaridade do lugar de entreteni mento-turismo constitui o seu dado sedutor e sua singularidade. 0 argumento aqui, enfim, consiste em que a rubrica espetacular desses espaços singularizaos como lugares. E consistem em lugares temáticos, quer dizer, especial izados e funcionais em um mapa que os relaciona a outros lugares e dimensões temporais. A tematização necessariamente está na interface tanto com uma historicidade própria ao anelado de condições que emoldura o lugar e, ao mesmo tempo, relaciona-se com o modo como o espaço évivido e sentido na sua singularidade estético-espetacular. M odo de experiência consoante com a modernização turística.

N esse sentido, retomo determinada sugestão de Dean M acCannel (1989). Para ele, vimos, no lugar turístico prevalece a encenação, 0 simulacro. M as, inspirado na teoria da reprodução técnica das condições de expressão humanas de B enjamin, ao conceber o turismo como exemplar do ímpeto de diferenciação, expansão sistêmica, desterritorialização e destradicionalização da modernidade, para 0 autor, a encenação consiste em uma invenção temática real izada por sistemas peritos, visando conferir "aura" aos elementos descontextualizados, em meio à dinâmica da modernização turística, para tornarem-se "atrações", distinguindo-os como dotados de uma propriedade que lhes é intrínseca, irreproduzível, logo, sublime ( $M$ acCannell, 1976, p. 13):

Há no conjunto das manifestações da retórica do turismo a importância da autenticidade na relação entre turistas e o que eles vêem: isto é a casa nativa típica; esta é a caneta usada para assinar a lei; este é o manuscrito original [...]. (M acC annell, 1976, p. 14)
Enfim, o lugar turístico seria resultante de uma racionalização em duplo sentido, seja do ponto de vista weberiano de uma dessacralização, na medida em que os móveis naturais e culturais têm suas respectivas semânticas de acordo com a diferenciação mesma da sociedade e consciência modernas ( $M$ acCannell, 1976 , p. 15) e recolhidos para o interior do "sistema de atrações" do roteiro turístico, seja devido ao exercício de reflexividade concretizado na estratégia discursiva do marketing em atribuir a essa totalidade sistêmica um sentido de exclusividade, por intermédio das combinações da verbalidade discursiva com a visualidade, os sons e cheiros. 0 viés de análise aí sugerido contribui para antever os canais de comunicação entre a sensibili dade dos consumidores de atrações turísticas e os enquadramentos institucionais e sistêmicos que as condicionam social e economicamente. A inda assim, 0 autor não coteja o fato de 0 texto turístico consistir em um metadiscurso e, desse modo, relega ao segundo plano o emaranhado dos processos sociodiscursivos, sendo este crucial à confecção da "aura" dos lugares, aura com a qual contracenam a divul gação, o comércio e a administração dos produtos do turismo. Da mesma maneira, são deixadas no biombo as implicações socioculturais e históricas contidas na especificação de um lugar turístico.

No caso desta análise sobre espacialidade na festa-espetáculo no ciclo junino em Caruaru, vejo como igualmente sugestivo supor o intercruzamento dos posicionamentos de agentes na esfera da cultura de mercado com os interesses que se perenizam nas políticas públicas para 0 setor cultural e nas modalidades de reciprocidade que forjam os elos entre aquelas políticas com os dispositivos do entretenimento e turismo. O ra, a estratégia de aproximação do problema exige recuperar, no modo como estão plasmadas no espaço, tanto as largas interdependências acima descritas, quanto as determinações macrossociológicas nelas inscritas. A o meu ver, o dado diferencial dessa ambiência-paisagem está exatamente na conjugação do espaço com intenções e atitudes, na maneira como ambos pautam as redes de diversidades e situam processos sociais de bitola mais larga. Por isso, 
tomo por corpus elementos que compõem a área hoje el eita como o epicentro dos festejos juninos em Caruaru, com o objetivo de resgatar, no empreendimento analítico, as condições das objetivações que se fazem cenário palpável à disposição dos agentes e das materialidades étnico-históricas e geográficas que constituem a paisagem da festa-espetáculo. Daí por que, nos parágrafos posteriores, remeto o leitor à interpretação cal cada no acesso a esse contexto permitido durante a pesqui sa de campo realizada entre 1996 e $1997 .{ }^{6}$

Situado no centro da cidade, inaugurado em 1994, o Pátio de Eventos L uiz Gonzaga consiste em um complexo de 41.500 metros quadrados, onde estão aninhados a Fundação de Cultura, os M useus do B arro e do Forró, um pavilhão de exposições, a sede da Secretaria M unicipal de Turismo, o grande pal co para shows e a Vila do Forró. A Vila do Forró é um conjunto de edificações cenográficas reproduzindo uma vila sertaneja, a da Conceição (que teria dado origem à cidade), na cor azul e amarela ou cerâmica. Em grande medida, ocupam o espaço bares e restaurantes, todos decorados tematicamente com motivos juninos e objetos da cultura material rural da região. São bal ões e correntes em papel colorido; peneiras e chapéus de pal ha e tábuas de bater carne; nas janelas, cortinas com babados e toal has bordadas nas mesas. I gualmente típico é o cardápio, no qual predomina a culinária local (feijão-de-corda, manteiga derretida em garrafa, assado de bode etc.). A inda compõem o cenário duas pequenas agências (a bancária e a dos correios), varandas para as noites de forró "pé-de-serra" e alguns banheiros estão lá instalados. A o fundo, uma pequena capela branca. $\mathrm{Na}$ parte externa, os grandes letreiros luminosos divulgam as marcas patrocinadoras do espaço, que tem um grande pórtico à entrada e uma imensa placa sinaliza ser aquele um dos endereços da "R ota do Forró" em Pernambuco. A centralidade do espaço é destacada nas estratégias discursivas de divulgação como índice de modernização dos festejos na cidade, atendendo aos critérios tácitos da demanda turística, isto é, conforto, segurança e higiene:

6. 0 mapeamento empírico fez parte do percurso da minha tese de doutoramento (ver Farias, 2001).
Depois de desembarcar do trem e passear pelo A rraial Vitalino, o turista chega no Pátio de Eventos Luiz Gonzaga, foco de animação do São João, com uma capacidade de $80 \mathrm{mil}$ pessoas. No Pátio de Eventos está situada a Vila do Forró, réplica de uma vila interiorana, com igrejinha, prefeitura, mercearia, postos de serviços, tudo é construído de alvenaria.

0 Pátio de Eventos nasceu da necessidade de adequarmos em um só espaço todas as festividades de rua da cidade, dispondo de estacionamento interno, completa estrutura de energia e água, piso pavimentado, que fazem desta área a mais e melhor estruturada do interior do estado. (Secretaria de Turismo de Caruaru, 1998)

A nota curiosa está no empenho que norteia a engenharia urbanística, a qual se inscreve na sua realização arquitetônica, em razão da clara decisão por parte do poder público municipal de central izar as comemorações em um só espaço. De certa maneira, reproduz-se em Caruaru algo já observado em relação ao carnaval de Salvador (Farias, 1998, p. 129), isto é, a mesma atuação coordenada pel o ordenamento do poder político local demarcando a fronteira da festa pública, aberta às multidões, ainda que as compactando em um espaço elaborado e enobrecido. Aí a multiplicidade humana, com suas al ternativas de expressão e meios de vida, se, de um lado, é homogeneizada como público, de outro, compete como o estofo que assegura o conteúdo de diversidade no evento, no instante em que as engrenagens de produção da festa se mostrem capazes de selecionar e reprocessar as alternativas criativas como atrações da programação festiva divulgada nos diferentes canais, de acordo com a especialização funcional e com a hierarquia de status, uma e outra instaurada desde a institucionalização e burocratização técnico-administrativa do festejo.

No entanto, os limites do Pátio de Eventos consagram um feixe de determinações sóciohistóricas sedimentadas a ser mais bem vislumbrado. Como em outras experiências, também a caruaruense conhece, ao longo das últimas quatro décadas, a aglutinação promovida e gerenciada pelo poder público, na contrapartida do aumento dos fluxos de visitantes enativos e na valoração das situações de diversão 
proporcionadas pelos festejos de São J oão, no rastro da expansão das malhas da sociedade urbano-industrial e de serviços. Vale traçar sumariamente alguns estágios observados no percurso das transformações experienciado pelo festejo. De acordo com o historiador N elson $B$ arbalho, ainda no final do século $X I X$, os festejos juninos na cidade já atraíam pessoas das imediações e mesmo de Recife. Porém, tratava-se de reuniões organizadas em casas particulares, chamadas de "palhoças", na área rural e urbana, congregando círculos mais restritos de vizinhança e amizade. Tais ocasiões combinavam modalidades de clientelismo e comensal idade, condicionantes de parentesco e, ainda, aportes mais homogêneos de classe, mas submetidos às designações do patrimonialismo, em um concerto social no qual a estrutura agrária da grande propriedade rural condicionava a dispersão e o dado centrífugo das relações sociais. No interior desse cenário, os festejos espalhavam-se sobremaneira na hinterlândia agrária. No início do século XX, o ciclo junino em Caruaru tornou-se afamado, pela divulgação na capital pernambucana do "Chalé de Olegário"; durante todo o mês de junho, sucediam-se

festas atrás de festas, fogueiras, balões, cangicadas, pamonhas, milho assado à vontade, fartura até dizer basta. Ele, sua família e inúmeros políticos situacionistas, todos os anos, repetiam a visita a C aruaru, todos encantados com os seus festejos juninos, que eram real mente sensacionais. (B arbalho, 1992, p. 47)

Certamente, tanto a expansão material da produção da festa, quanto 0 alto grau de popularidade dos festejos estão em correl ação com algumas das características marcantes da cidade, no mesmo século passado. O u seja, com a inversão de comando entre campo e cidade, ganhando predomínio as atividades aninhadas na última. Sobretudo, é no que diz respeito à função de entreposto que exerce Caruaru, mediando a distribuição das trocas entre o litoral e o sertão de Pernambuco, concatenando mais ou menos cinqüenta cidades, que novos fatores somados deslocam as condições de realização dos folguedos juninos. Embora sua origem como núcleo urbano esteja diretamente ligada ao lugar de intercâmbio entre tropeiros e boiadeiros, apenas em meados do século $X X$ as trocas já monetarizadas ganham significativo vulto e contribuem para a remodelação da dinâmica e da estrutura social local, em sintonia com a tendência centrípeta que se espalha em obediência aos imperativos do Estado racional-legal e 0 estágio urbano-industrial e de serviços da sociedade nacional. Não é à toa que, durante esse período, sua feira livre ganha prestígio, exal tada em canção de 0 nildo $\mathrm{A}$ Imei da como 0 local onde "D e tudo que há no mundo/N ela tem pra vender $[\ldots . .]^{\prime} .{ }^{7}$ A efervescência comercial de $C$ aruaru condicionou o ritmo mais intenso do movimento de sua urbanização, em relação aos outros municípios da região. A o mesmo tempo, o mesmo elemento co-participou da diferenciação entre os grupos sociais. A ssim, às palhoças domésticas, são acrescentadas as festividades em clubes, em um tipo de sociabilidade agrupando novos e emergentes grupos de perfil nitidamente citadino: comerciantes, profissionais liberais, funcionários públicos, empregados do setor bancário e todos que formavam o balbucio das classes médias e de uma sociedade civil com pontes erguidas com 0 ordenamento centralizado de poder e com a socialidade contratual ista engatada à dinâmica do mercado capital ista e sua sistemática monetária.

À semelhança de outras experiências, também em Caruaru é no interior desse alinhamento de novos grupos que emergirá a val oração da temática da identidade coletiva local e onde serão selecionados seus guardiões. No rastro da expansão da educação laica e de modalidades seculares de formação da opinião pública, o despontar de uma especialização técnica mais nítida de um modo geral e particularmente na

\footnotetext{
7. Do ponto de vista histórico, a feira existe há 143 anos e confunde-se com a formação da cidade em torno da atividade dos tropeiros - à maneira de Feira de Santana e Campina Grande, outras duas grandes cidades do A greste nordestino. Esse imenso mercado popular acompanhou a expansão urbana, mas, na década de 1980, foi deslocada da Rua Sete de Setembro, no centro, e fixada em uma ampla área, o Parque 18 de Maio. Aí trabalham cerca de dez mil feirantes. A importância da feira livre é reconhecida pelo poder público, que mantém o Memorial da Feira. A brigado no antigo Mercado da Farinha, o espaço reúne 32 painéis de fotos narrando a trajetória da feira.
} 
área cultural, incorporando o aumento significativo de literatos, educadores, músicos, jornalistas e compositores, reserva a oportunidade para que estes se firmem como grupos de status. Como o escritor e jornalistaJ osé Condé, voltados para o cotidiano e as raízes do município, os integrantes desse grupo buscam o ser coletivo nas manifestações e também desempenham decisivo papel à invenção de tradições sertanejas, ${ }^{8}$ el aboração posteriormente apoiada nos interesses de segmentos da elite política. Em grande medida, as formulações de ênfase regional daí decorrentes, no trato com a identidade cultural, ocorrem em observância da situação periférica ocupada pela cidade, seja diante da capital do estado, seja em relação à posição do N ordeste no contexto da sociedadenação, comandada pelo ímpeto industrial "sulista".

Tanto o desenvolvimento comercial quanto os novos segmentos sociais surgidos e os grupos incumbidos das questões da produção cultural, por outro lado, permitem a instalação e 0 desenvolvimento de mecanismos de expressão e significação mais afinados com a modernização dos hábitos. Naquele instante, as emissoras de rádio comerciais despontavam como ponta-de-lança do mercado da comunicação no país e da industrialização do simbólico. É justamente do interior de uma dessas empresas de comunicação recém-instaladas na cidade, mas empenhadas em efetivar sua marca junto ao público, consolidando uma audiência e assim solidificando uma posição no próspero comércio local, que partirá um dos lances com decisiva repercussão nas transformações no sentido da festa de São J oão em Caruaru. Isto se dá com

\footnotetext{
8. Para o historiador Eric Hobsbawm, a categoria "invenção de tradição" volta-se para os processos históricos e simbólicos que consistem na regulação por regras implícitas ou mesmo aceitas de um conjunto de práticas com a finalidade de assegurar a internalização subjetiva de "certos valores e normas de comportamento através da repetição, o que implica, automaticamente, uma continuidade em relação ao passado" (Hobsbawm e Ranger, 1997, p. 9). De acordo ainda com a visada do autor, o que é crucial para tais invenções é o deslocamento das práticas do mundo social comum, trasladando-as ao terreno genérico de sinais de uma "comunidade", em torno da qual valores comuns devem ser compartilhados como obrigações de caráter moral. A garantia de eficácia simbólica dos artefatos inventados estaria justamente no distanciamento em relação às inconstâncias, às diversidades e aos enfrentamentos de interesses entranhados no cotidiano.
}

a decisão da emissora em promover concursos de ruas ornamentadas ${ }^{9}$ e marcar uma diferença nos festejos juninos caruaruenses. A qui, diria, manifesta-se um decisivo lance de ressignificação de tradições, já calcado na valoração do ser regional caruaruense. No entanto, 0 procedimento é associado a aspectos cuja pressão age sobre a natureza mesma da matriz sócio-simbólica, cujo arco de valores pauta a narrativa sobre as origens e fundamentos locais.

Vale a pena detalhar 0 argumento a respeito dessa invenção de tradição. Não há dúvidas de que já se dava a expansão das pal hoças para os espaços públicos da cidade, formando os arraiais, nos quais a participação de anônimos faz inflar o peso da opinião e do gosto público sobre os festejos. E estes são redefinidos como palcos para o ritual de transmissão de saberes e agora a entrega da memória já está ordenada pelas condições urbanas e sob a coordenação dos dispositivos políticos e ideológicos responsáveis pela valoração da noção unitária de passado comum, a ser compartilhada pelos nativos daquele torrão. Com a competição centrada no universo da rua, porém, o dado do concurso introduz um elemento dramático e espetacular na exigência de que os festejos adquiram caráter público. Ou seja, posto aos olhos de anônimos, as sociabilidades festivas deverão se mostrar capazes de fisgá-los; deverão confortá-los pelos efeitos resultantes do cál culo das adições realizadas na produção do festejo, agora reconhecido como evento por depender do sucesso dos acontecimentos que o possibilitam. Do ponto de vista operacional, a espetacularização desenha-se à medida que os moradores das ruas passam a organizar mutirões visando dividir entre si o ônus dos gastos com os ornamentos. $\mathrm{E}$, ao mesmo tempo, esmeram-se em reunir aspectos que se tornam atrativos ao público e jurados. L ogo, sanfoneiros, quadrilhas, pau-de-sebo, mazurcas, cirandas, laça-laça e mesas e barracas com iguarias e bebidas típicas dão colorido aos cenários. N esse mesmo andamento, para assegurar o sucesso da empreita na competição, os moradores começam a eleger comissões de rua e estas são

9. Coube a um forasteiro a autoria da inovação. Publicitário e radialista, Lídio Cavalcanti introduziu o concurso em 1962, logo após fixar residência na cidade, vindo de Recife. 
incumbidas de acionar e buscar recursos para a realização da festividade. Cada vez mais terão ascendência o patrocínio dos comerciantes e a ajuda do poder público e/ou de políticos, ambos interessados nos dividendos el eitorais a serem recol hidos como resultante da dádiva.

A combinatória desses fatores rebate-se como um motor de sucção recolhendo insumos à ampliação da base sociocultural da festa. Sua extraordinária popularização manifesta-se nas cada vez maiores multidões presentes às ruas, público estimado em mais de quinhentas mil pessoas nas noites principais, em 1999. Para 0 que muito contribuiu as emissoras de rádio, que tornam o São J oão uma atração a mais de suas respectivas programações e tendo decisiva incidência sobre os limites e a natureza das territorializações do festejo. Vejamos em que medida. De um lado, na contrapartida da drenagem da densidade festiva de outras áreas da cidade e mesmo municípios adjacentes, a concentração trouxe 0 despertar do interesse comercial, de ambulantes ou de empresas formalizadas. De outro, da mesma maneira, o crescente acúmulo humano passou a exigir a manutenção de diferentes serviços públicos aumento do efetivo policial, bombeiros, fiscalização, entre outros. A grupados todos esses fatores de pressão sobre a realização do festejo, a intervenção do poder municipal dá-se mediante iniciativas de disciplinar o uso do espaço. É quando se decide por concentrar os festejos, sobremaneira no curso da última década de 1980, ao montar o arraial da cidade ao longo da Avenida Rui B arbosa. A iluminação reforçada e a decoração, centrada no imenso pórtico, localizado na abertura do território junino municipal, qual ificam aquele como o espaço por excelência, o espaço do São J oão de Caruaru.

É elucidativa, a respeito da intervenção do poder municipal no controle espacial, a iniciativa da administração de Caruaru em 1998 de encomendar, a uma empresa de arquitetura, a confecção de um mapa do território festivo do São J oão. A justificativa estaria na importância desse documento, seja para a distribuição dos serviços no espaço, ${ }^{10}$ seja para facilitar a visua-

10. Cabe ao Departamento de Eventos da Secretaria M unicipal de Turismo a distribuição dos alvarás para a instalação de barracas e a permissão para atuação dos vendedores am- lização das trajetórias dos visitantes, indicandoIhes os pólos de atração e de localização justamente daqueles serviços. Contudo, o próprio mapa consiste em um equipamento com ação sobre os modos de percepção e cognição do cenário da festa e da afirmação simbólica desse lugar como um locus distinto do seu entorno, demarcado-os em obediência ao esforço de disciplina inscrito no projeto, isto é, da racionalização evidenciada pelo mapa, mas já anteriormente em ação, pois impõe-se como necessidade de formatação da situação do festejo. Por isso, é sugestivo observar esse espaço longo, mas contíguo, batizado respectivamente de "A rraiá Vitalino" e "Corredor do Forró". A o longo da linha férrea, são setecentos metros entre o grande pórtico instalado na esquina das Avenidas A gamenon $M$ agalhães e $R$ ui B arbosa até o Pátio de Eventos. L ogo na entrada do circuito, bangalôs cenográficos, decorados com cestos, redes, raladores, abanos e tapetes de palha, abrigam lojas de comida típica. A o lado, abre-se um pátio para os dançarinos de forró ou para a apresentação de equipes de quadril has diante de nove degraus de arquibancadas e um palco, dotado de parafernália elétrico-eletrônica de som e de luz, sobre o qual se apresentam grupos musicais locais. M argeando toda a Rua Frei Caneca, são dispostos quiosques. Além dos banheiros, aí estão instalados dois restaurantes, lojinhas de suvenires, bares, lanchonetes e os estandes da prefeitura, dos blocos de drilhas e de empresas patrocinadoras do evento. Próximo à entrada do Pátio de Eventos, onde a chaminé da velha Fábrica Caruá ostenta o letreiro luminoso com o slogan "a capital do forró", estátuas reproduzem em formas ampliadas e cores fortes peças do artesanato ceramista local, justamente ilustrando as bandas de pífanos e os trios de forró de pé-de-serra.

\footnotetext{
bulantes. Em relação às primeiras, em 1998 e 1999, a decisão foi entregar os alvarás aos quarenta primeiros barraqueiros posicionados na fila de espera, que se forma no período de inscrição. A iniciativa teve por justificativa garantir a lisura da ação do poder público. A justificativa mostra-se claudicante diante das pressões provenientes da importância desse comércio informal para complementação ou para assegurar alguma renda, em uma região onde os baixos salários da mão-de-obra ocupada e o desemprego são acentuados. Mesmo porque os lances do clientelismo político ocorrem, muitas das vezes, tendo por alvo o favorecimento na distribuição dos alvarás.
} 
Podemos concluir o quanto as ideologias tecnicistas e de valoração das tradições locais se auto-engendram no perfil do festejo como megaevento. Naturalizada como gestora e guardiã da festa, coube à prefeitura decidir e escolher o que merece pertencer à arquitetura do evento. Portanto, o empreendimento de organizá-lo requer a designação de um quadro permanente que se ocupa das tarefas afins, tendo a coordenação de pessoas já envolvidas com as questões da cultura local. A prerrogativa a ser tomada como critério essencial é o respeito às "tradições" juninas caruaruenses. Diante desse parâmetro, as atrações passam a ser selecionas e distribuídas, em uma espécie de jogo estabelecido entre diferentes redes de segmentos da cidade e o poder público. Isto porque a adoção de prêmios e concursos, mesmo subvenções, contribui para o ingresso de novos integrantes e acrescenta variações ao festejo, estendendo-0 pelo decorrer do mês de junho, al go fundamental ao preenchimento da programação turística da festa mediante as várias prestações de serviços de lazer e fornecimento de bens de diversão. Em 1999, foram 120 músicos contratados, al ém de cantores e bandas de prestígio nacional e batal hões de bacamarteiros, trio de sanfoneiros, banda de pífanos e quadril has, que tiveram seus serviços remunerados com a finalidade de que el es recepcionassem os turistas chegados tanto no "trem" quanto no "vôo" do forró. Também quarenta quadrilhas, entre as estilizadas e as matutas, provenientes de Caruaru e de outras cidades e estados nordestinos, estavam inscritas no concurso oficial, com torneios diferenciados para ambas as categorias.

A aceleração da divisão técnica do trabalho e das funções na realização da festa encontra suporte no aparecimento de empreendimentos privados na promoção de eventos. A s empresas esmeram-se na organização de acontecimentos espetaculares, que retenham e confortem os gostos de diversão dos públicos. A ssim, é o caso da empresa A ugusto Eventos, responsável pela chamada "Caminhada do Cuscuz". Sob a justificativa da degustação do "maior cuscuz do mundo", a passeata regada por toneladas de "quentão" (preparado al coólico típico da festa) é composta por uma multidão arrastada pelo som de quatro trios elétricos, tocando forró por cerca de nove quilômetros até o distrito do $\mathrm{A}$ Ito do M oura. Da mesma maneira, o aumento do fluxo de visitantes e mesmo 0 de nativos no epicentro da festa fomenta outros empreendimentos, partindo também da iniciativa privada empresarial, tendo em vista a exploração comercial de facetas do evento. A ssim, as casas de shows ligadas ao forró (como o Palladium) começam a transferir para a rua os seus serviços mais sofisticados de bar e restaurante e ainda contratam artistas de prestígio regional e nacional para apresentações durante o período junino. Já os hotéis empenham-se em divulgar seus pacotes na perspectiva de atender à demanda por vagas: suas publicidades trazem à frente as atrações embutidas no festejo local. E isto vai se articular com o empenho das agências de viagens em estabelecer conexões com as congêneres de Recife e vender serviços completos de transportes, hospedagem, alimentação e visitação. ${ }^{11}$ Seria exaustivo elencar, detal hadamente, todos os encadeamentos de condutas. 0 que importa é ressaltar 0 anel de comprometimentos que se forja, no enlace gerado entre os aspectos fiscais e políticos eleitorais com 0 impacto sobre a remuneração do capital e a otimização, embora temporária, de uma mãode-obra de seis mil pessoas e elevando em $30 \%$ a arrecadação do município (Secretaria M unicipal de Turismo, 1999). É confrontado pelas pressões provenientes desse arco que o poder

11. Cito dois exemplos a respeito. 0 "trem do forró" surgiu em 1990, a partir do acordo da agência de turismo Serambi, sediada em Recife, com a Prefeitura de Caruaru, tendo respaldo nos responsáveis pelos equipamentos hoteleiros da cidade. A mplamente divulgadas nos meios de comunicação, as partidas e chegadas são saudadas por fogos de artifícios e pelo pipocar de bacamartes. Já o trajeto do trem (da capital pernambucana até a "capital do forró"), a cada edição, em média, realizado por quatro mil passageiros, é animado por trio musical de tocadores de forro pé-de-serra, grupos de quadrilha e outros grupos folclóricos. 0 "vôo" segue 0 rastro de sucesso do "trem", porém tem por alvo um público de poder aquisitivo mais elevado, como define Edson Rosal, proprietário da agência de turismo Rosal, de Caruaru, responsável pelo negócio. Antigo gerente de banco, Rosal explicou ao autor que o empreendimento deveu-se a uma proposta original da Companhia A érea TAM, que faz o transporte dos passageiros do A eroporto Guararapes, no Recife, até Caruaru. Trata-se de um vôo panorâmico, incluindo no roteiro a paisagem do litoral, na área do balneário de Porto de Galinhas, e a região agrestina. A terrissados em Caruaru, os visitantes, também recebidos com as pompas juninas, são deslocados para o hotel e daí aos camarotes montados no Pátio do Forró. 
público se manifesta, redimensionando o espaço do São J oão, ao construir o Pátio de Eventos.

Pressões decorreram da envergadura adquirida por fórmulas de sociabilidade de diversão móveis como as drilhas. Tendo por nicho sociológico as redes de amizades de facções mais jovens das classes médias, desde a metade final da década de 1980, inspiradas nos comportamentos jocosos que marcam o folclore junino (como o "casamento na roça"), mas agora no rastro do modelo carnavalesco de Salvador, as drilhas, organizações de cunho empresarial, começaram a percorrer em formato de passeatas os dias de festa, embaladas por bandas e cantores sobre trios elétricos, arrastando, entre suas cordas, multidões vestidas segundo o tema que define cada um dos blocos. A incipiência empresarial das entidades e o grau de informalidade da atividade conferem certa improvisação e precariedade aos serviços ali realizados. M esmo porque a drilha não tem registro jurídico. Segundo uma das responsáveis por uma das organizações, os custos com a contratação da mão-de-obra (desde as funcionárias até o cantor do trio elétrico, passando pelos técnicos em som e luz, seguranças e cordeiros, além dos artistas contratados para decorar os carros al egóricos apresentados) são cobertos pela venda das cotas de patrocínio, que dão direito aos anunciantes de exibirem suas marcas nos cartões de inscrição, camisetas, nas laterais tanto do trio el étrico quanto do carro de apoio (ou "camarote móvel") e, ainda, nas inserções de divulgação na televisão.

Se a prefeitura, através das Secretarias de Turismo e de Cultura, esforça-se para enquadrar as drilhas nas diretrizes por ela traçada, impondo dias, hora e local determinados para os desfiles - cabendo às mais antigas escolher o dia da passeata - , há um somatório de fatores favoráveis à ampliação do empreendimento, do qual o poder público local não pode abrir mão. Vejamos. A procura de lugares entre as cordas das drilhas aumenta extraordinariamente de ano a ano e, assim, juntamente, todo o aparato empresarial e organizacional necessário para fazer frente às demandas ganha vulto (cordei ros, fiscais e seguranças, carros de apoio, quadro de funcionários etc.). Fatores que dispõem as drilhas na busca de maior contingente de participantes e, ao mesmo tempo, estimulam 0 aparecimento de novas associações afins. Verifica-se nas drilhas algo semelhante já observado em Salvador, a saber, a concentração de prestígio e poder na mão da iniciativa privada e a ocupação dos espaços públicos para a comercialização da participação cosmopolita nos festejos. A s dificuldades, no entanto, decorrem do respaldo tanto do público, sobretudo dos adolescentes e jovens que dão suporte social para as organizações, quanto dos profissionais da área artística musical, que vislumbram no cortejo dessas entidades um espaço a mais de atuação remunerada. ${ }^{12} 0$ aspecto sociologicamente interessante é o comparecimento da mesma situação já observada nos blocos de trio elétrico da capital baiana, na qual a focalização do público jovem como um alvo define estratégias, mas igualmente assinala o mesmo componente estrutural na condução das atitudes dos responsáveis pelas drilhas, ou seja, a intervenção do mecanismo institucional do entretenimento. Pois a contrapartida da predominância da clientela jovem nos bem-sucedidos e novos eventos no interior dos festejos juninos está no desl ocamento da ênfase nas modalidades de divulgação da festa, realçando seu reconhecimento como um dos nichos da cultura de diversão.

A mensagem da imagem publicitária é heurística a respeito, já que nela o acento é cada vez maior nos elementos sensuais e despojados das sociabilidades festivas do São J oão, aproximando-se assim de uma folia. E esses são recoIhidos nos móveis acústicos e coreográficos vinculados à semântica do forró, como dispositivo estético capaz de promover situações de êxtase. Ora, a centralização discursiva no universo dos signos identificados ao público jovem viabiliza tal deslocamento, pois aí está concentrada a valoração de práticas referentes à satisfação promovida pela intensificação das emoções, mediante $o$ teste dos limites afetivos.

\footnotetext{
12. Embora prevaleça o recorte geracional e etário na caracterização das drilhas, afinal a Babydrilha é dirigido a crinças e a Piradrilha têm por alvo, principalmente, adolescentes, ainda assim as tensões entre gênero e identidade sexual são relevantes. No contra-ataque à proibição de muIheres na $M$ achadrilha, na qual apenas desfilam homens fantasiados de mulher, surgiu exclusiva às mulheres a Gaydrilha.
} 
M as o deslocamento se faz em uma espécie de reciclagem dos traços da tradição rural do forró. A foto oficial do São J oão de Caruaru, em 1999, é ilustrativa, até porque a cena da foto guarda semelhanças com as capas de revistas dedicadas ao desvelamento da intimidade de pessoas famosas do mundo artístico e esportivo, ou mesmo com anúncios publicitários, nos quais o padrão de beleza dos modelos é indicativo de um ideário de sofisticação proposto como intrínseco aos objetos anunciados. $\mathrm{N}$ a fotografia, dois modelos vestem roupas com elementos que sugerem o clima junino (como o xadrez na padronagem das camisas de ambos e o chapéu de palha), tendo por fundo a fachada de uma igreja e próximos das chamas que fazem arder uma fogueira. A o mesmo tempo, há os sinais de uma esportiva descontração, que os diferenciam de um casal de caipiras convencionais. Ele, um atlético moço al to em justa calça jeans; ela, morena de sorriso largo, longos e brilhantes cabel os castanhos divididos ao meio, tendo fitas vermelhas nas pontas, de saia vermelha, mas vestindo uma blusa preta, decotada. A imagem oferece suporte material à combinação entre os signos de juventude e etnicidade, agora trasladados como ícones da temática que diferencia o evento de Caruaru no esquema funcional da economia do lúdico.

Com isto, a reciprocidade entre o empresariamento e a atuação do poder público ganha a cada ano contornos tensos e contraditórios, quando toca nas negociações em torno da manutenção da "tradição" local. Sabendo se tratar da narrativa básica à tematização turística da festa, em meio à recriação dos sentidos da festa e sua ef etivação como parte da cultura de entretenimento e da economia do lúdico. Exemplar a respeito é o concurso de quadrilhas, divido entre as categorias de grupos "matutos" e "estilizados". A ocasião do concurso manifesta o que é representado na publicidade como um confronto entre tradicional e moderno, cuja luta se faz diante e visando à conquista do destaque na transmissão televisiva da TV Tribuna, uma das promotoras do evento, e da multidão que ao vivo assiste às exibições. A verificação da origem social dos grupos demonstra o quanto, em sua maioria, eles têm por base colégios e associações comunitárias laicas ou religiosas, situadas em áreas periféricas urbanas. $\mathrm{N}$ as apresentações, em ambas categorias, salta aos olhos uma mesma tendência concretizada nas cenas montadas, ou seja, o resultado é fruto de pesquisas na busca de materiais e técnicas capazes de proporcionar impacto visual sobre a audiência, em uma atitude próxima da e similar ao do formato passeata-espetáculo da escola de samba. Se os "matutos" dão primazia à reedição das situações em torno da história do casamento caipira, reatualizando nos movimentos da dança os passos que guardam traços de danças da corte francesa (como o rondó), fazem-no dentro do rigoroso cumprimento de um roteiro e da recriação da cena caipira, para a qual os tons mais austeros nas cores das roupas e o estudo dos gestos corporais, hiperbolizando os manejos jocosos, exigem a especial ização dos componentes, como atores de uma trupe teatral popular. Já as quadril has estilizadas priorizam a renovação temática anual, a partir daí incorporando a transformação dos figurinos e adereços, além dos desenhos coreográficos. Dão preferência ao brilho e colorido no manejo com os tecidos, complementos e plásticos, realizando performances inspiradas em movimentos aeróbicos.

A instituição da competição, portadora da exigência de observância dos quesitos, sem dúvida, joga um papel marcante para o delineamento de contornos espetaculares na brincadeira das quadrilhas, mas a compreendo mais como uma expressão, em lugar de considerá-lo o ponto deflagrador da mudança. B uscar um ponto zero para a espetacularização que aí se insinua neste ou naquel e grupo parece-me equivocado. Creio estar os el ementos da transformação na situação mesma na qual os grupos de quadrilha se enquadram na interação viabilizada pela competição; situação constituída por eventos e performances alinhadas ao propósito de plasmar públicos, cuja expectativa é alimentada pela divulgação da aura que cobre a festa de São de J oão de Caruaru como prenhe de potenciais para fazer eclodir momentos de prazer, al egria, beleza, enfim, emocioná-los. A própria distinção entre "matutas" e "estilizadas", encampada na categorização nativa que os agentes fazem a respeito do elo e da estima que os homogeneíza como grupos e lhes conforma as práticas, revela 
como o dado folclórico e popular ocupa posições complementares no esquema de atrações turísticas e de diversão na festa. Já que a oposição aí consiste em lugares especificados de sinais que se complementam no estabelecimento do texto do evento dotado de diferentes atrações e não em contradições acerca de um mesmo ponto.

A curiosa e dúbia atitude do poder público local manifesta-se sobretudo na defesa tenaz da cor tradicional da festa, pois está na mesma via de mão dupla na qual o outro sentido consiste no estímulo à promoção comercial do festejo junino local. Por exemplo, durante a conversa com a chefe do Departamento de Eventos da Secretaria de Turismo de Caruaru, a frase mais repetida por ela foi a "defesa da cultura local", o que considera decisivo para diferenciar o São J oão caruaruense daquele real izado em Campina Grande. A iniciativa de real çar a diferença, em uma das suas facetas, responde à pressão de acentuar a distinção entre as duas cidades no interior da competição turística e da batal ha para assegurar patrocinadores. Para isto, reivindica a "profissionalização" do evento, no que tange à produção eà administração. A Igo assim já estaria na raiz do sucesso obtido em áreas como os serviços de alimentação no Pátio de Eventos, ao ser aberta uma licitação para a contratação de serviços de restaurantes e lanchonetes. 0 mesmo teria ocorrido com intervenção de uma agência de publicidade, prestando serviços relativos à venda das cotas de patrocínios, isto é, à comercialização dos espaços de maior apelo visual, incluindo aí o foco das câmeras de televisão. Entretanto, os mesmo critérios técnicos e comerciais são mitigados quando se trata da instal ação de casas de venda de bebida e comida na região do A Ito do M oura - é categórica em aprovar a suspensão, por parte da prefeitura, dos alvarás para abertura de novos comércios. A lega que a atividade de bares e restaurantes deturpa a "tradição" ceramista daquela região.

A inda assim, a defesa da tradição local pelo poder público não está a salvo de contradições, na medida em que a dimensão cultural do consumo é compartil hada por distintos matizes das redes que proporcionam a festa. Os diferentes grupos, ao compartilharem do mesmo imperativo da exposição e da visibilidade, também deflagram modalidades de aparição e concorrência entre si. A atenção à citada região do Vale do M oura é el ucidativa. A o se tratar de uma região rural há pouco transformada em uma área periférica suburbana, o bairro tem apenas uma das suas ruas pavimentadas e é nesta principal artéria onde se instalam bares e restaurantes, enfileirados e frente a frente. Porém, no grande pórtico situado à entrada da via mais importante, há a informação sobre ajustes inusitados, se considerarmos o posicionamento da chefe do Departamento de Eventos. Ali, contendo réplicas dos bonecos de Vitalino e frases saudando e situando o visitante, estão lado a lado as siglas da Empresa Pernambucana de Turismo e, também, da Secretaria de Turismo de Caruaru, mas também de patrocinadores. Os estabel ecimentos comerciais são acanhados, fazendo coro com as demais edificações de casas de alvenaria sem embolso, entre as quais aquela que abrigou a família do célebre mestre Vitalino. Em muitas das moradias, a venda de cervejas e churrasco de bode é complementar ao comércio de peças de cerâmicas.

De acordo com os objetivos deste artigo, não interessa averiguar até que ponto ocorre a interferência e a superposição de uma atividade sobre a outra. Importa identificar o arranjo de forças com impacto sobre a transmissão da memória e com incidência na condução das práticas culturais. Porque em um e outro momento aqui focalizado, que compõem a festa de Caruaru, o el emento galvanizador éo mesmo: 0 forró, isto é, o sentido de festa instaurado em torno das redes de sociabilidades alegres, promovidas pelo ritmo dançante do repertório musical identificado à tradição junina sertaneja. É mediante esse demiurgo que a contradição no posicionamento da chefe do Departamento de Eventos mostra-se heurística do processo que analisamos. 0 dado conflituoso revela os intercruzamentos entre política cultural e entretenimento e turismo como fatores nodais à compreensão da maneira como as relações sociais estruturam-se na viabilização da festa. A heuristicidade do forró decorre de que se trata da categorização de uma realidade na qual, vimos, se entretêm as estratégias e táticas contidas nos movimentos de invenção eressigni- 
ficação da tradição sertaneja nordestina, núcleo temático do local de entretenimento e turismo caruaruense. $M$ as também das modalidades emergentes de hierarquização e exclusão socioculturais aí inscritas.

Nesse sentido, é coerente pincelar o modo como a intervenção das políticas públicas municipais, tendo por objeto o patrimônio cultural na cidade, interage com a montagem da ambiênciapaisagem na festa-espetáculo. Em 1996, é alterada a finalidade da Fundação de Cultura e Turismo de Caruaru, devendo agora ater-se ao patrimônio histórico municipal, porém, antes, ao patrimônio contido nos símbolos e práticas da cultura popular. A final, no artesanato ceramista e nos festejos juninos, são reconhecidos os diferenciais locais, enraizados na mesma tradição pletora da identidade coletiva da cidade, guardada nos M useus do Barro e do Forró, sob jurisdição da fundação. $M$ as vejamos o próprio texto da Lei Orgânica do M unicípio, no seu Capítulo III, dedicado à administração indireta do poder público, no qual é promovido o desmembramento das atribuições dos órgãos; doravante as questões propriamente turísticas escapam aos propósitos daquela repartição do poder público. 0 olhar mais detido sobre 0 conjunto do texto da Lei Orgânica do M unicípio, contudo, revela um significado outro para os remanejamentos realizados na atribuição das respectivas competências desses órgãos do poder público. Pois, se a princípio a instauração da Secretaria de Turismo desincumbiria a Fundação de Cultura do trato com os aspectos pertinentes ao comércio turístico, é mais que notório: os produtos turísticos por excel ência de Caruaru inscrevem-se na tradição sertaneja, da qual a fundação é a guardiã. U ma e outra instância estão umbilical mente referidas. Especificamente, a instauração da Secretaria de Turismo, antes de tudo, compreende uma resposta local à densidade na rede de reciprocidades constitutivas do evento festivo da cidade.

Por sua vez, a secretaria corresponde ao redimensionamento do quadro administrativo, à maneira como Weber descreve a burocracia na dominação racional legal, ou seja, a legitimação do poder calcado no conhecimento adquirido pela experimentação e documentação. Conhe- cimento co-substancializado no exercício qual ificado e técnico do profissional remunerado, caracterizado pelo saber prático do serviço restrito ao âmbito do seu interesse de atuação, na sistemática das habilidades e das funções da associação (Weber, 1992, p. 144-147). No caso de Caruaru, à inserção de técnicos em turismo na engenharia administrativa, corresponde esse parcelamento das competências. $M$ as o reforço da natureza racional da dominação legal, por sua vez, reintegra as atividades de um e outro órgão no objetivo engl obante de otimizar os recursos simbólicos do município, de acordo com o conceito de desenvolvimento turístico. Algo sugerido na congregação, na mesma área edificada do Espaço Cultural Tancredo N eves, de ambos setores da administração municipal, além dos seus objetos diretos de intervenção os museus e o sítio composto pelo grande pátio dotado de equipamentos para espetácul os, a Vila do Forró e o pavilhão de exposições. A formalidade da redação da L ei Orgânica, na Seção X, referente às atribuições da Secretaria de Turismo, em particular as do Departamento de Eventos, evidencia com nitidez tanto o encadeamento funcional que, vimos, norteia o setor turístico, como descortina o quanto é decisiva para a atuação da repartição a interface com a produção e com as políticas culturais, na consecução do já referido objetivo de desenvolvimento.

Embora haja uma parcela importante desse discurso implicado em uma estratégia inspirada no projeto cultural identificado aos interesses do poder público local, na interface com interesses da iniciativa empresarial e do programa turístico estadual enacional, não creio consistir na mel hor opção de compreensão reduzir tais representações, tão-somente, a manifestações da vontade de dominação de um grupo ou feixe de grupos. Porque, observando as três facetas apresentadas acima, entre as muitas presentes na festa-espetáculo do São J oão, e o modo como são expressas, o que parece importante é como os meios de orientação vinculados aos aportes institucionais do entretenimento impõem-se sobre o horizonte possível das consciências e, por outro lado, são alterados profundamente os recursos para as formas assumidas pelas exteriorizações humanas. 
Desse ponto de vista, não se trata apenas de uma direção unilateral de coação, advinda do plano interno, sobre o perfil assumido pelo festejo ou o simetricamente contrário; na verdade, a deflagração das pressões resulta de forças que atravessam e interpenetram, simultaneamente, planos distintos das cadeias sociofuncionais, ajustando modos e meios de produção, além de universos simbólicos e suportes de poder e dominação. E isto mostra-se evidente, quando se relaciona o evento de Caruaru no contexto mais amplo do tema da cultura popular nas últimas décadas, em que é potencializada a prerrogativa de uma economia simbólica, para qual espaços e práticas significantes detêm elevado valor de comercialização na convergência entre mídias, mercados e formatos de expressão, tanto na montagem de domínios de memórias e correção de narrativas com efeitos sobre as identidades (gênero, étnicas, geracionais efaixas de idade, regionais e mesmo nacionais), quanto na definição de estilos de vida. Assim, as interseções entre matrizes culturais e também esferas especializadas no desenvolvimento das atividades de serviços e suas repercussões no plano das atividades instrumentais e das moralidades levam a negociações em torno de imagens de mundo e delimitação de territorialidades que envolvem instâncias locais, nacionais, internacionais e transnacionais. $M$ as se tais engates são marcantes nos enfrentamentos político-econômicos naqueles fóruns em que são decididas as linhas gerais dos conceitos de bens e dos patrimônios culturais (Canclini, 1990), ainda assim os remanejamentos na gerência da cultura na cidade são também correlacionados à tendência de valorização crescente dos bens simbólicos e do próprio espaço como suportes de uma identidade local. ${ }^{13}$ Com isto, as concatenações de tão diversas redes acomodam as diversidades étnico-históricas na montagem da ambiência-paisagem do

13. A o falar das tensões geradas no engate nação e região, 0 antropólogo Rubem Oliven supõe que, para a emergência de uma atitude pelo menos sensível ao significado da diferencialidade entre os padrões de conduta coletiva, um dos fatores decisivos seria a importância assumida pelo debate e pelas reivindicações em torno das fontes de significado e reconhecimento, isto é, as identidades. A despeito das fórmulas calcadas em uma apreensão linear dos processos sociais, argumenta ele, em várias partes do mundo, sempre ciclo junino e são notórios os rebatimentos da construção desse lugar do entretenimentoturismo sobre as atitudes, já que intervêm nas valorações e nas possibilidades expressivas e comunicacionais dessas diversidades sóciohumanas.

\section{Considerações finais}

A propagação das paisagens-ambiência dos lugares de entretenimento-turismo está no caudal do encadeamento composto também pela segmentação de mercados de consumidores de largas proporções, ao lado da redefinição dos poderes públicos cada vez mais atrelados às pressões geradas com a criação de novas centralidades que vazam os nichos urbanos, exigindo alternativas e capacitando-os a atrair business. A rranjo, ainda, formado pelas coordenadas de desregulamentação das investidas dos agentes do mercado capitalista, com impacto sobre o Estado-nação no que diz respeito aos deslocamentos de poder aliados à descentralização de decisões, aumentando a margem de manobra dos governos locais e regionais perante o domínio das elites nacionais. Isto, na contrapartida do novo model o de desenvolvimento implementado desde instâncias multilaterais como o B anco M undial eo B ird, de acordo com o qual as agendas de investimentos sempre mais priorizam o conceito de cultura ("modo de vida"), dando ênfase à reinvenção de tradições, na contraface do apelo à "comunidade" como foco prioritário de gestão e criatividade (Hermet, 2002, p. 15-16). Tal como entende Zigmunt $B$ auman, a emergência de tais territorialidades vem na esteira do tipo de codificação pósmoderna em favor de gratificações. De acordo com 0 autor, na contemporaneidade, as faixas de tempo são desencadeadas pela lógica moderna de progressão e da segurança, com isto, 0 adiamento das satisfações é cada vez mais substituído em prol da felicidade e da liberdade

mais elementos simbólicos conectados a tradições ganham relevância no reconhecimento das estimas pessoais e dos grupos. Isto porque, na contrapartida da oxigenação dos afetos pessoais e dos grupos, estariam os exercícios de afirmação das diversidades, os quais se dariam sobre o mesmo terreno de uma globalidade ávida em sincronizar, apagando as distâncias que facultam a incomensurabilidade entre as culturas (Oliven, 1992, p. 13-29) 
individual. A mbas são apelos de uma agenda voltada ao agente competente em fazer escol has adequadas à realização da promessa de sensações agradáveis, a despeito do torvelinho de insegurança gerado conjuntamente pelo somatório egoísta dessas condutas hedonistas (B auman, 2003, p. 82).

Incluídas nas redes do comércio e das prestações de serviços de lazer e diversão, as festas-espetáculo são cada vez mais importantes pontos nas estratégias de desenvolvimento que ora articulam símbolos, espaços e a dinâmica do capital, vinculando-se à modalidade de poder transterritorial aliado à parceria entre economia simbólica e sistema do desejo da sociedade de consumidores. Entretanto, as al terações nos gestos visando reinstaurar algum senso de cosmo estão em correlação com a ascensão desses lugares temáticos, se consideradas as demandas candentes de pertencimento e de estabilidade ontológica em um cotidiano atravessado exatamente pelo fremir dos trânsitos acel erados. 0 ingresso das sociabilidades festivas regionais populares em um circuito com apelo na divulgação das mídias, e nos roteiros turísticos, faz dueto com as reivindicações de territorialização dos círculos hermenêuticos de reconhecimento em um presente diáfano, graças ao "encurtamento" espaço-temporal do planeta. 0 comunicólogo J osé M arques de $\mathrm{M}$ ello, por exemplo, enxerga a revalorização do folclore como uma faceta da globalização, no instante em que esta implica processos de desterritorialização e esquecimento histórico. A cultura popular tradicional reintroduziria "[...] a qual idade e o concreto (a felicidade, 0 amor) na vida real, multiplica as relações afetivas, estimula sem cessar a vida pessoal [...]" (M arques de M ello, 1997, p. 25).

0 estudo das repercussões das festasespetáculo, na estruturação das condutas dos agentes e nos planos institucionais do ciclo junino em Caruaru, faz cruzar as duas perspectivas na compreensão do engendramento mútuo das margens à proliferação de diversidades étnicohistóricas com a expansão generalizada do modo de vida urbano-metropolitano pelo conjunto do país e sua contrapartida nos "desencaixes" e "reencaixes" das relações sociais, no escopo do quais são acionadas estratégias e táticas de reconstrução de referenciais de pertencimento e sobrevivência e postos em relevo outras reivindicações por reconhecimento das estimas e de valoração de imagens de indivíduos e grupos. 0 que, por sua vez, inclui o rol das imaterialidades, mais especificamente do processamento do conhecimento como informação e os acessos e usos desses bens simbólicos com os devidos suportes midiáticos nas lutas correlacionadas à distribuição de recursos urgentes à manutenção ou ao estabelecimento de status. Se o desenho das territorialidades articula aportes físicos com horizontes de entendimento e fórmulas de sobrevivência articuladas a possibilidades de escol has e de legitimação de sentidos imputados, nas texturas contemporâneas - à maneira dos lugares de entretenimento-turismo - , a delimitação do específico é cúmplice da extensão complexa das redes sociofuncionais.

De um lado, a ênfase na identidade define uma agenda de debates pautando planos existenciais e coletivos em escala cada vez maior de grupos humanos a respeito da confiança nas interações dispostas na contrapartida das comunidades de comunicação erguidas sobre a crença em alicerces ontológicos compartilhados. L ogo, os processos de localização e suas devidas conceituações correspondem ao estágio sóciohistórico em que as complementaridades dispõem as ações, desempenhos e narrativas (com seus móveis simbólicos) em eixos proporcionalmente mais cosmopolitas. M ovimentos que, simultaneamente, envolvem 0 acirramento da concorrência entre as mesmas formações culturais, pois são travados enfrentamentos sócio-simbólicos entre atores nos encadeamentos dispostos em fronteiras porosas e as pugnas deixam evadir uma polifonia de vozes, ávidas em ganhar visibilidade nos fóruns transterritoriais da opinião pública, para corrigir interpretações ou afirmar carismas. Isto traduz, por outro lado, como os novos posicionamentos estão sendo demarcados na penetração conjunta da cultura de consumo e de novas tecnologias de informação/comunicação na arquitetura inerente a essas redes sociofuncionais extensas e sobressaem em âmbitos distintos, notadamente na esfera cultural. Como espaço elementar à construção de legitimidade de consensos estru- 
turada na filtragem institucional dos saberes que constrangem a compreensão social, e portanto dispõem os alvos dos discursos e decisões públicas, tal esfera repercute no cotidiano por intermédio das gramáticas, repertórios semânticos e formatos expressivos que informam tanto o estilo quanto o alcance dos diálogos e dos desempenhos. Conclui-se que os tipos de trabal hos acionados, os agenciamentos institucionais que viabilizam os nexos entre o gradiente heterogêneo de participantes, o montante de recursos financeiros e monetários gerados, os dispositivos de recriação de memórias e de formas de sociabilidades, a incidência das políticas públicas e conexões com as indústrias culturais (audiovisual, fonográfica, editorial) fazem da economia da cultura no B rasil contemporâneo, nos seus vários circuitos de eventos (moda, esporte, religião, lúdico-artístico, feiras, entre outros), um tema prioritário.

\footnotetext{
A bstract: As it has as its doject the circuit of artiaulated events within the spectacle party in which the June cycle is celebrated in Canuanu (PE), the punpose of this article focuses on the extended nets of dense, mutual socialfunctional dependencies and their unpredicted effects on the symbolic universe and practice systems. In order to achieve that, it is doserved the reciprocity between formal and informal levels adjusted to the entertairment schemes, regarding the configuration of tourist-entertaiment zones in the city by the means of a triangulation composed by the matrix of popular culture and the managements of the monetarized market in the elaboration and use of ludic expressions, together with the offer of entertairment services and the resources of govermental power. The emphasis of the analysis is on the configuration of the space of festive sociability both in the vectors that conform with the entertairment logics and in the elements that create temporary fonms of struggle, negotiation and public-emotional acknowledgment.
}

K ey words: spectacle party; june cycle in Canuaru; diversity and entertairment.

\section{Referências}

A PPA DURAI, A rjun. N otas para uma geografia pósnacional. Novos Estudos Cebrap, 49, nov., 1997.

AUGÉ, M arc. Espacio y alteridad. Revista do Occidente, n. 140, enero, 1993.

. Por uma antropologia dos mundos contemporâneos. Rio de J aneiro: B ertrand, 1997.
BA RBA LHO, N elson. Caruaru: nomes e cognomes. Caruaru: Vanguarda, 1992.

Caruaru: Sua prefeitura. Sua autonomia municipal. Sua emancipação política. Caruaru: A rt Berg, s.d.

BA UM A N, Zigmunt. Em busca da política. Rio de Janeiro: J orge Zahar Editor, 2000.

. M odernidade líquida. Rio de J aneiro: J orge Zahar Editor, 2001.

Comunidade: a busca por segurança no mundo atual. Rio de J aneiro: J orgeZahar Editor, 2003. BOURDIEU, Pierre. A economia das trocas simbólicas. São Paulo: Perspectiva, 1992.

. Efeitos do lugar. In: BOURDIEU, Pierre(Org.). A miséria do mundo. Petrópolis (RJ): Vozes, 1998.

BOORSTIN, Daniel J. The image: A guide to pseudo-events in A merica. N ew York: A theneum, 1973.

CANCLINI, Nestor. Culturas hibridas. México (D.F.): Grijalbo, 1990.

Consumidores e cidadãos. Rio de J aneiro: Édit. UFRJ, 1995.

CA STELLS, M anuel. The information age. Economy, society and culture. USA/U K : Blackwell, 1996, Vol.I.

ELIA S, N orbert. Sobre o tempo. Rio de J aneiro: J orge Zahar Editor, 1998.

EISENSTADT, Shmuel Noah. A dinâmica das civilizações (tradição e modernidade). Lisboa: Cosmos, 1991.

FA RIA S, E dson. U ma reflexão sobre a autofagia do concerto tradição brasileira e sociedade-nação. Revista Tomo, vol. 7, São Cristóvão (SE): UFS, 2004.

. Ócio e negócio: festas populares e entretenimento-turismo no B rasil. Campinas, 2001. Tese (D outorado) - Unicamp.

Novas paisagens urbanas e identidades socioculturais. Revista Lugar Comum, n. 4, jan.-abr., 1998.

FIORI, José Luís. A riqueza de algumas nações. Revista Praga, n. 8, p. 23-35, 1999.

GINZBURG, Carlo. 0 queijo e os vermes: o cotidiano e as idéias de um moleiro perseguido pela Inquisição. São Paul o: Cia das L etras, 1987.

HERM ET, G uy. Cultura e desenvolvimento. Petrópolis (RJ): Vozes, 2002.

HOB SB AW M , Eric; RAN GER, T. A invenção das tradições. Rio de Janeiro: Paz eTerra, 1997.

IB GE - Instituto B rasileiro de Geografia eE statística. Censo Demográfico do B rasil. CD-ROM . 2002. 
LA SH, Scott \& URRY, J ohn. E conomies of signs and space. L ondon: Sage, 1994.

M ACCNELL, D ean. Staged authenticity: arrangements of social space in tourist settings. American J ournal of Sociology, vol. 79, 1973.

. The tourist: new theory of the leisure class. N ew Y ork: Schocken B ooks, 1989.

MARQUES DE MELL 0 , J osé. Cultura, folclore e identidade regional. In: SIM PÓSIO DO ENCONTRO CULTURA DE LARA NJEIRAS, 21, 1997. Laranjeiras. Anais..., L aranjeiras (SE): janeiro, 1997.

M IRA, M aria Celeste. Invasão de privacidade? Reflexões sobre a exposição da intimidade na mídia. Revista Lugar Comum, n. 5-6, p. 9-14, 1999.

NICOLAS, Daniel Hirnaux. Elementos para uma análisis sóciogeográfico del turismo. In: RODRIGUES, A dyr B . (Org.). Turismo e geografia: reflexões teóricas e enfoques regionais. São Paulo: Hucitec, 1996.

OLIVEN, Ruben George. A parte e o todo: a diversidade cultural no B rasil-nação. Petrópolis (RJ): Vozes, 1992.

ORTIZ, R enato. U m outro território. São Paulo: Olho d'Água, 1999.

. Sociedade e cultura. In: SACHS, Ignacy; WILHEM , J orge; PIN HEIRO, Paulo Sérgio (Orgs.). Brasil: um século de transformações. São Paulo: Cia das L etras, 2001.

SACK, R.D. Place, modernity and the consumer's world. B altimore: The J ohns Hopkinks U niversity Press, 1992.
SA NTOS, M ilton. A natureza do espaço. São Paulo: Edusp, 2002.

SCHA M A , Simon. Paisagem e memória. São Paulo: Cia das L etras, 1996.

SECRETARIA DE TURISM O DE CARUARU. A tradição do São J oão. Caruaru (PE): Prefeitura M unicipal de Caruaru, 1998. [mimeo]

SIM M EL, Georg. A aventura. In: Sobre la aventura (Ensayos filosóficos). Barcelona: Ediciones Península, 1988.

SORKIN, M ichael. Introduction: variations on a theme park. In: SORK IN, M ichael (Ed.). A theme park. N ew Y ork: Hill and Wang, 1992.

TA M B IA H, Stanley Jeyaraja. Culture, thought, and social action. Cambridge/L ondon: Harvard U niversity Press, 1985.

THOMPSON, John B. A mídia e a modernidade (uma teoria social da mídia). Petrópolis (RJ): Vozes, 1998.

TRIGO, L uis Gonzaga. Viagem na memória: guia histórico das viagens e do turismo no B rasil. São Paulo: Senac de São Paulo, 2000.

WEBER, M ax. E conomia e sociedade. Brasília (DF): UnB , 1992, v. 1.

ZUKIN, Sharon. Postmodern urban landscapes: mapping culture and power. In: LASH, Scott \& FRIEDM A N, J onathan (Orgs.). M odernit \& identit. M assachusetts/O xford: B lackwell, 1992. 